\title{
133. Cytological Studies of the Anterior Pituitary in the Broody Fowl
}

\author{
By Mikio YASUdA \\ Faculty of Agriculture, Nagoya University \\ (Comm. by K. Masui, M.J.A., Dec. 14, 1953)
}

Payne $^{7)}$ (1943) believes, that the broody cells are found only in broody hens and that these cells may be concerned with prolactin production. Yamashina ${ }^{13}$, (1952) states that in the brooding fowls induced by prolactin injection three kinds of reactions were observed: namely (1) degeneration of testes, (2) revelation of broody behavior, and (3) suppression of molt.

The purpose of this study is to describe the cytological and histological changes that occur in the anterior pituitary of the broody fowl, and also to determine the cytological site of the cause which induces the broodiness.

The present work was done under the guidance of Prof. K. Masui (Emeritus Professor of Tokyo University) to whom I wish to express my heartiest thanks. I also wish to offer my thanks to the Ministry of Education and Tokai Gakujutsu-shorei-kai for their financial assistance.

\section{Materials and Methods}

As materials, twenty-seven hens of Nagoya were used, of which fourteen hens were in various broody periods. The pituitaries of the laying Nagoya were removed during the period of first clutch of laying, in order to obtain a better basis for comparison and to reduce the variations which take place usually in pituitaries of laying hens.

All pituitaries were fixed by the method of Severinghaus (1932), of Cleveland and Wolfe (1932), and were stained after the same authors' methods. Paraffin sections were cut serially at $3 ;$ in the sagittal plane.

\section{Results}

The anterior pituitary of the adult fowl is distinctly bilobed as has been noted by $\mathrm{Rahn}^{8)}$ (1939), and these lobes are designated as "cephalic" and "caudal". These two lobes are intimately related developmentally, but they are cytologically distinct. In the caudal lobe the acidophiles are more abundant than in the 
cephalic lobe, and the granules of them are stained bright scarlet to red in preparations treated with the afore-mentioned technique. These cells contain large, coarse, and irregular granules with a striking affinity for the acid fuchsin. The granules of the acidophiles of cephalic lobe are very light acidophilic which are stained violet to purple by Severinghaus' technique. The same granules are also stained orange instead of red after Cleveland and Wolfe's method $^{1)}$ (1932) and are distributed throughout the peripheral zone of the cephalic lobe.

The pituitaries of broody hens show marked transformations by the fifth day of the broody period. The acidophiles of the caudal lobe are fielld with secretory granules, which are stained red with acid fuchsin. At the beginning of the broody period, these cells are round or oval in shape and border on the blood vessels, showing a cluster in contact with blood sinus and its branches (Fig. 3). At the middle of the broody period the acidophiles of the caudal lobe increase significantly in number. They

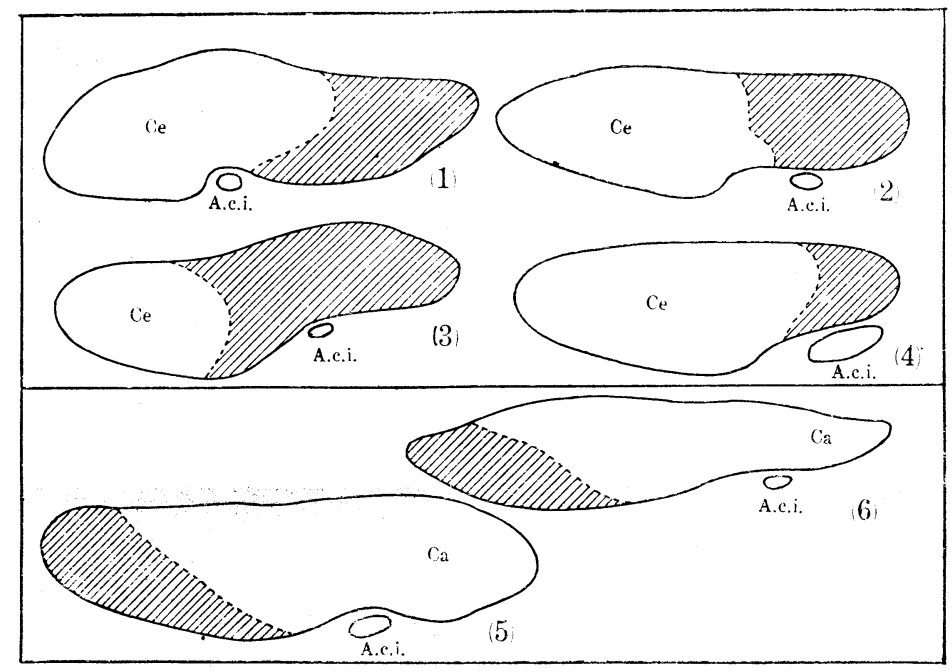

(1): Hen No. 42, broodin $\mathrm{ss}$ continued for 10 days. (Z): Hen No. 41, broodiness continued for 10 days. (3): Hen No. 19, broodiness continued for 20 days. (4): Hen No. 23, broodiness continued for 20 days and mothering care for 4 dxys. (5): Hen No. 16, broodiness continued for 5 days. (6): Hen NJ. 21, broodiness continued for 19 days. (5) and (6): Showing the pituitaries of exceptional hens. Ce: Cephalic lobe. Ca: Caudal lobe. A.c.i.: Internal carotid artery. Plain white: Basophilic cell zone. (iblique hatching: Acidophilic cell zone

Fig. 1. Outlines of mid-sagittal sections of the anterior pituitaries of six different broody hens 


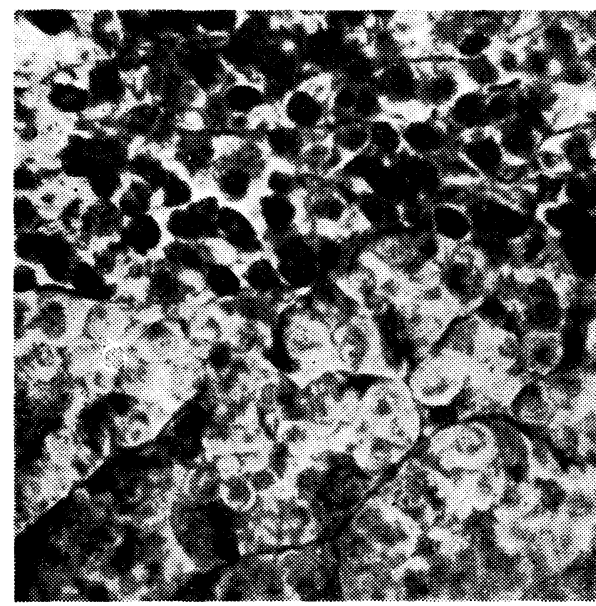

Fig. 2

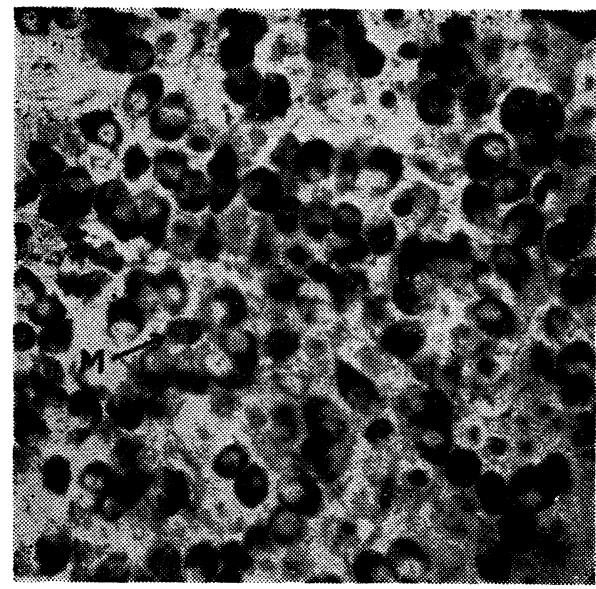

Fig. 4

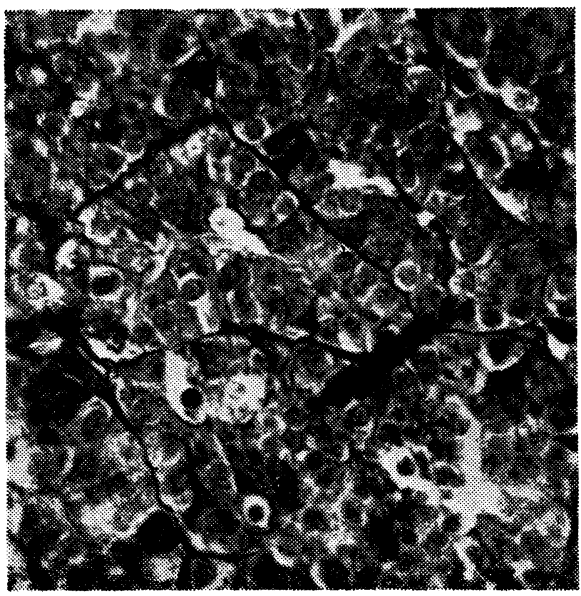

Fig. 6

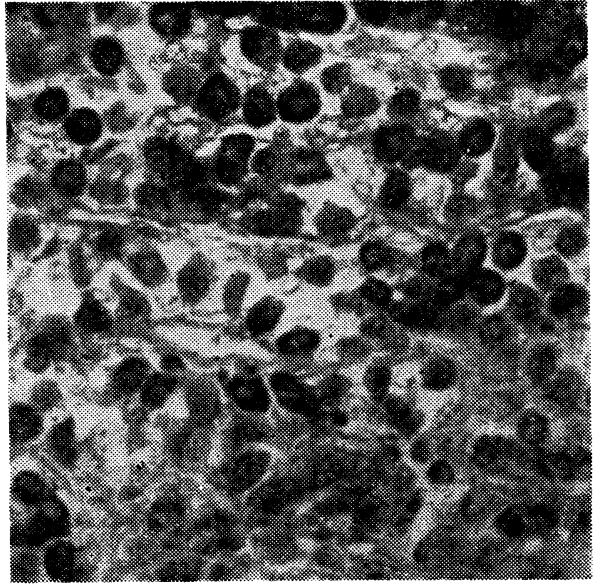

Fig. 3

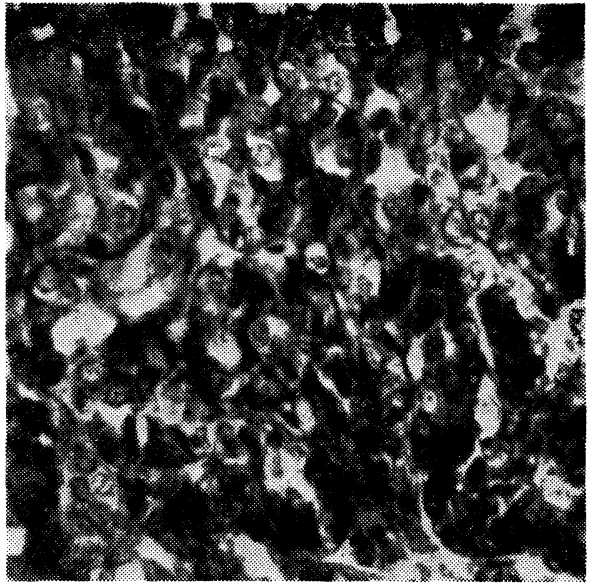

Fig. 5

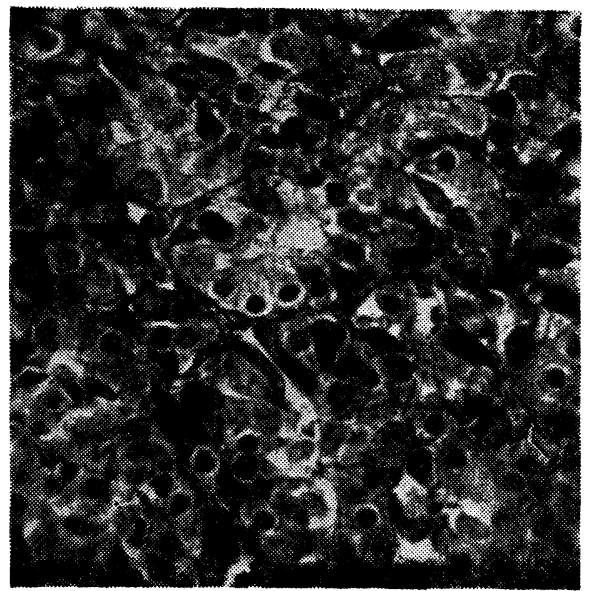

Fig. 7 
Fig. 2. Mid-sagittal section of the anterior pituitary of broody period. The upper part shows caudal region of the anterior pituitary, and the lower part, cephalic region.

Fig. 3. Caudal lobe (5 days of broody period), showing slightly granulated acidophilic (carminophilic) cells (dark) scattered along the blood vessels and ordinary acidophiles (gray)

Fig. 4. Caudal lobe (20 days of broody period), showing the characteristic red-coarse granules. Note, the distinct macula ( $M_{1}$ of 8 carmino cells.

Fig. 5. Caudal lobe (24 days of broody period), showing a part adjacent to an internal carotid artery. In this part all acidophiles revert to their chromophobes.

Fig. 6. Cephalic lobe (24 days of broody period). All basophiles revert to their chromophobes. These cells are designated as "broody cell" by Payne.

Fig. 7. Cephalic lobe (24 days of broody period). By the reverse process chrom $>$ phobes change into basophilic form.

are large in size and somewhat elongated. Their nuclei are also large in size and appear clear. Five or six nucleole are found in them. Most of cells which contain bright scarlet granules appear to be active in hormone secretion. At the periphery of the gland adjacent to the carotid artery, the acidophiles are so abundant that whole cords are often entirely filled with them. These cells have a tendency toward an alveolar arrangement, and macula are involved within cell groups. In each cell of this cluster the nucleus lies between the lumen of a follicle and the granular Golgi-zone (Fig. 4). These characteristics of acidophiles are most striking in the caudal lobe of the broody hen. At the last period of broodiness the nuclei of acidophiles become smaller in size and their granules are reduced in number. Some acidophiles of caudal lobes seem to be inactive. With regard to the shape, number and distribution of the granules, the basophiles of the caudal lobe have the same characteristics as those in the laying fowl.

Another series of changes of basophiles during the broody periods are conspicuous. The basophiles of the cephalic lobe at the beginning of the broody period show remarkable changes. The cytoplasm becomes reduced, and non-granular and the mitochondria become fewer in number. The nuclei of these cells are stained much darker than those in the laying period. At the middle of the broody period characteristic evidence is also presented as a result of a study of pituitaries of the most striking broody fowls, indicating that the basophiles revert to their chromophobic form (Fig. 6). These small chromophobes dominate almost exclusively and small cells are closely gathered into large cell cords. The nuclei are large and clear büt cytologically typical resting nuclei. The 
mitochondria are present in these cells as in the chromophobe. The slightly chromatic nucleus with one or two intensely staining nucleoli is surrounded by a slender margin of cytoplasm. The clear cytoplasma devoid of granules, except the mitochondria, takes only a faint basophilic stain. At the end of the broody period the nuclei of the chromophobes are stained emerald green with methyl green, and these cells as a whole are large in size, and cyanophilic flocculent granules are numerous. Such cells might be interpreted as illustrating a phase of the transition between chromophobe and basophile. The return changes of such basophiles are conspicuously marked in Fig. 7. The acidophiles of cephalic lobe show no significant changes, and are probably active in hormone secretion. But some of acidophiles are small in size and the granules of the cytoplasm are much darker red in contrast with the purple of active cells.

The caudal and cephalic regions of the anterior pituitary are well established as a morphological entity on the fifth day of the broodiness. There are no correlations between the range of acidophilic zone and the broody period (Fig. 1. (1), (2), (3), and (4)) . Even at low magnification these two regions are clearly differentiated. Typical examples of them are seen in Fig. 2.

In all the pituitaries of broody hens the above-mentioned results are observed, with exception of only two individuals in which the distribution of cells is quite different. In these individuals the acidophiles are dominant in the cephalic lobe, while the caudal lobes are small in size and their cells are chromophobic (Fig. 1. (5), (6)).

Results of quantitative cell analysis from broody hens during fifth to tenth, eleventh to twentieth, and twenty-first to thirtieth day of broody period reveal the fact that there are many significant differences from those of laying hens. Cell counts of the acidophiles of the caudal lobe indicate that at eleventh to twentieth day of broody period the relative parcentage of these cells is 52.9. Another series of changes are the decrease in number of basophilic cells of cephalic lobe. By the middle of the broody period, the relative percentage of these cells is reduced to 3.2. Few cells of this type remaining in the regions exhibit an extreme reduction of granular material. During the subsequent broody period the granules of basophiles begin to appear and increase a staining intensity. A marked increase in the percentage of the basophiles is shown with a parallel decrease in the relative percentage of the non-granular chromophobic type.

Table I shows the relative percentage of the various cell types 
found in the broody period of hens.

Table I

Distribution of cell types

\begin{tabular}{|c|c|c|c|c|c|c|c|c|c|c|c|c|c|}
\hline \multirow{3}{*}{$\begin{array}{l}\text { Repro- } \\
\text { ductive } \\
\text { stage }\end{array}$} & \multirow{3}{*}{$\begin{array}{l}\text { Number } \\
\text { of hen }\end{array}$} & \multicolumn{6}{|c|}{ Mexn percentage of cell types } & \multicolumn{6}{|c|}{ Mean number per field } \\
\hline & & \multicolumn{3}{|c|}{ Caudal lobe } & \multicolumn{3}{|c|}{ Cephalic lobe } & \multicolumn{3}{|c|}{ Caudal lobe } & \multicolumn{3}{|c|}{ Cephalic lobe } \\
\hline & & $\mathrm{a}$ & $b$ & $\mathrm{c}$ & $\mathrm{a}$ & $\mathrm{b}$ & $\mathrm{c}$ & $\mathrm{a}$ & $\mathrm{b}$ & $\mathrm{c}$ & a & $\mathrm{b}$ & $\mathrm{c}$ \\
\hline $5-10^{+}$ & 5 & 44.2 & 18.8 & 37.0 & 5.2 & 3.5 & 91.3 & 44.1 & 18.6 & 37.3 & 29.9 & 19.6 & 50.5 \\
\hline $11-20$ & 4 & 52.9 & 17.0 & 30.1 & 14.9 & 3.2 & 81.9 & 61.8 & 19.8 & 18.4 & 14.9 & \begin{tabular}{|l|}
4.1 \\
\end{tabular} & 81.0 \\
\hline $21-30$ & 5 & 31.5 & 15.6 & 52.9 & 24.1 & 16.5 & 59.4 & 31.7 & 15.5 & 52.8 & 28.8 & 15.6 & 55.6 \\
\hline Laying & 5 & 30.4 & 18.2 & 51.4 & 29.8 & 19.8 & 50.4 & 30.8 & 17.6 & 51.6 & 30.0 & 19.8 & 50.2 \\
\hline
\end{tabular}

\section{Discussion}

It is of interest to compare the cyclic histological changes in the anterior pituitaries of the laying hens with those of the broody hens.

Examination of anterior lobe tissue of broody hens during fifth day of the broody period shows that the caudal lobe and the cephalic lobe present two cytologically and histologically different regions. In general, the cephalic lobe of these hens contains chromophobes, usually light staining acidophiles and few mature basophiles, while the caudal lobe contains deep staining, coarsely granular acidophiles, basophiles, and few chromophobes. The acidophiles of caudal lobe are considered to be distinct from the acidophiles of the cephalic lobe. These cells contain the granules which have a striking affinity for the azocarmine dye. These cells have been named the "Carmine cell" by Dawson ${ }^{2)}$ (1939), and recently, Dawson" (1946) has referred to this cell as the "Carminophile". Fig. 4 illustrates some of the morphological and staining characteristics of this cell. Friedgood and Dawson ${ }^{5}$ (1942), on the basis of their observations, concluded that the carmine cells contained a luteinizing hormone, and suggested that these cells might be associated also in some way with other gonadotropic functions of the adenohypophysis, since they were present in extraordinarily large numbers in the cat's hypophysis during the last week of pregnancy and early lactation. Schooley and Riddle ${ }^{9)}$ (1938) observed that, during the first week of incubation, the acidophiles of the pigeon's hypophysis increased in number, and this condition was maintained until the end of feeding of the young. From this evidence they concluded that prolactin arises from the acidophiles. Everett and Baker ${ }^{4)}$ (1945) showed an in- 
crease in acidophile percentage after parturition and at a time of lactation, and believed that the increased granulation of acidophiles is associated with the high lactogen content of the hypophysis. A year later, Dawson ${ }^{37}$ (1946) made a study of the effects of nursing and lactation on the carminophiles of the adenohypophysis of the cat, and recorded the observation that nervous stimuli resulted in rapid elaboration and release of secretory products by the carminophiles.

In this present experiment, the acidophiles of the caudal lobe were greatly increased in early broody period, rising from 30.4 per cent in late laying to a maximum of 52.9, and at the end of the broody period they are gradually decreasing in number to reach a level of 31.5 per cent. On the other hand, by the first week of the broody period the relative percentage of the basophiles of the cephalic lobe is markedly reduced from 19.8 per cent in laying to 3.2 at the middle of the broody period. Coincident with the decrease in the percentage of the basophiles of the cephalic lobe there occurred an increase in the chromophobes of this lobe. It is an impression gained from the observation that chromophobes seem to originate from the basophilic granular cell as the result of a loss of granules. Evidence favorable to this assumption is also presented that in the cephalic region, by the reverse process, the basophiles revert to their chromophobic form.

Payne (1) (1943) referred to chromophobic cells as "broody" cell, and believed that the broody cells of fowls might be homologous to the "pregnancy" cells of mammals. However, there is a discrepancy in his observation and assumption. He says: "There are dangers even in suggestions. Broody cells cannot be the only source of prolactin because extractions and assays demonstrate its presence at other times". From the facts above-mentioned it is reasonable to consider that these chromophobes of the cephalic lobe are not a new type of cell, but they are similar to the cells of the definitive gland as to the cytological aspect.

It is worth noting that small undeveloped ovaries are found without exception in the broody hens in the present study. Yamashina ${ }^{13)}$ (1951) reported an interesting result. According to him, cocks were laid in the dark room for nine days and then prolactin was given to them by injection; the testis of the cocks so treated showed the degeneration of germ cells, and the broody behavior began to appear. It seems to be necessary that in the broody period of the hens the gonadotrophic activity is maintained at the low level, and that the striking changes of basophiles of the cephalic lobe are associated with their small degenerated ovaries. 
On the basis of these data above-mentioned, together with those above discussed facts, we came to the conclusion that the carminophilic acidophiles of the caudal lobe are the only source of prolactin, and therefore the "broody" cells of Payne are just chromophobic cells whereby the ovaries are maintained on the undeveloped condition during the broody period.

\section{Summary and Conclusion}

1. From the existence of correlation between cytological and physiological data it can be inferred that prolactin is secreted by the acidophiles (especially carminophile), whereby it maintains the functional behavior of broodiness.

2. As for the revert of basophiles to their chromophobic form, it is considered to be essential for the initial cause and for subsequent keep of broodiness.

3. The granules of the acidophiles, which seem to secret prolactin, have an affinity to acid fuchsin dye. From the conditions, observed in the histological preparation in the present study it is difficult to believe that this acidophile is a new type of cell. Friedgood ${ }^{6)}$ (1946) and White ${ }^{11)}$ (1949) believed that the different affinity to dye in these cells was due to a functional phase of the secretory cycle of the acidophiles. The observations of the present study are fairly in agreement with Friedgood's view ${ }^{6)}$. More recently, Wilson ${ }^{2)}$ (1952) demonstrated the two kinds of acidophiles of the fowl. But, in regard to the detailed classification of these cell types the data are not sufficient enough to give a definite answer in these experiments.

\section{References}

1) Cleveland, R. and Wolfe, J. M.: Differential stain for anterior lobe of hypophysis. Anat. Rec., 51 (1932).

2) Dawson, A. B.: Differential staining of the anterior pituitary gland of the cat. Stain Tech., 14 (1939).

3) Dawson, A. B.: Some evidences of specific activity of the anterior pituitary gland of the cat. Am. J. Anat., 78 (1946).

4) Everett, N.B. and Baker, B. L.: The distribution of cell types in the anterior hypsphysis during late pregnancy and lactation. Endocrinology, 37 (1945).

5) Friedgood, H. B. and Dawson, A. B.: Inhibition of the carmine-cell reaction in the pituitaries of cats which mate but do not ovulate. Endocrinology, 30 (1942).

6) Friedgood, H. B.: Endocrinic function of the hypophysis. Oxford Univ Press (1946).

7) Payse, F.: The cytology of the anterior pituitary of broody fowls. Anat, Rec., 86 (1943). 
8) Rahn, H.: The development of the cellular differentiation of the pars buccalis. J. Morph., 64 (1939).

9) Scholey, J. P. and Riddle, O.: The morphological bisis of pituitary function in pigeons. Am. J. Anat., 62 (1938).

10) Severinghaus, A. E.: A cytological technique for the study of the anterior lobe of the hypophysis. Anat. Rec., 53 (1932).

11) White, A.: The chemistry and physiology of a len ohypophyseal luteotropin (Prolactin). Vitamins and Hormones, 7 (1949).

12) Wilson, M.E. : The embryological and cytolog:cal basis of regional patterns in the deninitive epithelical hypophysis of the chick. Am. J. Anzt., 91 (1952).

13) Yamashina, Y.: Notes on experimental brosding induced by prolactin injections in the domestic cock. Annot. Zool. Japon., 25 (1952). 